\title{
Peranan Orang Tua dalam Mengembangkan Kecerdasan Emosional dan Spiritual (ESQ) Anak dalam Perspektif Islam
}

\author{
Zahrotul Badiah \\ MI Yaspi Kaponan, Kecamatan Pakis, Kabupaten Magelang \\ zbadiah@gmail.com
}

DOI: 10.18326/mudarrisa.v8i2.229-254

\begin{abstract}
Abstrak
Kecerdasan emosional dan spiritual (ESQ) merupakan penggabungan kecerdasan emosional untuk membentuk hubungan dengan sesama manusia, dan kecerdasan spiritual yang membentuk hubungan dengan Allah, sehingga pada akhirnya akan membentuk hubungan dengan Allah dan sesama. Asmaul husna adalah kunci dari perkembangan emosional dan spiritual dalam membentuk akhlak yang mulia, karena sumber suasana hati manusia adalah asmaul husna itu sendiri. Selain hal tersebut peran orang tua dalam periode kehidupan seorang anak sangat penting, karena dapat menentukan lebih lanjut tumbuh kembang anak. Oleh karena itu, orang tua harus memberi kesempatan kepada anak-anak untuk tumbuh dan mengeluarkan ide-ide bagus secara emosional dan spiritual pada anak-anak. Dengan demikian, orang tua turut berkembang untuk mengembangkan kecerdasan emosi dan spiritual pada anak-anak. Hal-hal yang mempengaruhi kecerdasan ESQ adalah hubungan dalam keluarga itu sendiri adapun hubungan yang bersifat spiritual bisa melalui ibadahibadah ritual semacam shalat, puasa, berdzikir selalu mengingat Allah. Selain itu orang tua juga harus menanamkan prinsip-prinsip kebajikan pada ruh anak. Dalam tulisan ini penulis memaparkan banyak hal-hal yang mempengaruhi ESQ.
\end{abstract}

Emotional and spiritual intelligence (ESQ) is an amalgamation of emotional intelligence to form relationships with fellow human beings, 
and spiritual intelligence that formed a relationship with God, so that it can form a relationship with God and human beings. Asmaul Husna is a key of emotional and spiritual development in shaping ahlakul karimah, because the source of human mood is asma al-husna itself. The roles of parents in the period of a child's life are very important, because it can determine further developments. Therefore, parents should give an opportunity to children to grow and expend good ideas, in emotional and spiritual ways to children. Thus, parents should try to develop emotional and spiritual intelligence of children. ESQ is affected by the relationships within the family itself and the relationship for the spiritual nature can be through some sort of ritual forms of worship prayer, fasting, always remember Allah. In addition, parents should also inculcate principles of virtue in the spirit of the child. In this paper the author exposes many things that affect ESQ.

Kata kunci: kecerdasan, emosional, spiritual

\section{Pendahuluan}

Pendidikan sudah menjadi kebutuhan primer yang harus dipenuhi dan tidak dapat dipisahkan dari kehidupan masyarakat serta menjadi kewajiban dan tanggung jawab bersama antara orang tua, masyarakat dan negara. Untuk memenuhi kebutuhan pendidikan tersebut, masyarakat mempunyai pandangan bahwa sekolah merupakan lembaga pendidikan yang secara potensial memiliki peranan paling strategis bagi pembinaanpembinaan generasi muda sehingga menjadi pribadi yang tangguh dan mengembangkan potensi dalam dirinya tanpa mengesampingkan nilai moralitas. Meskipun sebenarnya sekolah hanyalah merupakan satu diantara berbagai lembaga pendidikan yang dapat mempengaruhi pertumbuhan dan perkembangan generasi muda menuju kedewasaan

Keluarga merupakan pranata sosial yang di dalamnya terdapat anggota-anggota yang terdiri dari ayah, ibu, dan anak. Keluarga memiliki 
fungsi yang strategis bagi pembentukan pribadi anak. Dalam kaitannya dengan fungsi edukatif ini, lingkungan keluarga memberikan pengaruh yang sangat besar dan menentukan dalam pendidikan anak. Keluarga memberikan pengaruh yang sangat besar dan menentukan dalam pendidikan anak. Keluaraga lingkungan awal anak, disadari atau tidak disadari akan langsung berpengaruh terhadap pendidikan anak.

Asumsi masyarakat tersebut amat berbeda dengan hasil riset otak yang mengatakan bahwa terbaru yang mengatakan bahwa kecerdasan intelektual (IQ) bukanlah ukuran kecerdasan yang sebenernya. Ternyata kecerdasan emosional yang menentukan seseorang yang memperoleh kesuksesan hidup. Namun bayak pula yang telah meraih kesuksesan namun ia merasakan kekosongan dalam jiwanya, disebabkan oleh kurangnya nilai-nilai spiritual yang diterimanya. Konsep kecerdasan spiritual dirasa sangat penting dan diperlukan ditengah era globalisasi ini. Dengan memiliki kecerdasan spiritual yang memadai, seorang anak akan mampu mengendalikan diri dan mengembalikan segala peristiwa yang dialaminya kepada Allah SWT.

IQ dan EQ tidaklah cukup untuk membawa diri kita, masyarakat maupun bangsa ini dalam kebahagian hakiki, masih ada nilai lain yang perlu diperhatikan yaitu kecerdasan spiritual atau SQ. Artinya, IQ memang penting kehadirannya dalam kehidupan manusia, yaitu agar manusia bisa memanfaatkan teknologi demi efisien dan efektifitas. Juga peran EQ yang memegang peran begitu penting dalam membangun hubungan antar manusia yang efektif dan sekaligus peranannya tanpa SQ 
yang mengajarkan nilai-nilai kebenaran, maka keberhasilan itu hanyalah akan melahirkan hitler-hitler atau fir'aun-fir'aun kecil di bumi.

\section{Metode Penelitian}

Jenis penelitian ini pada penelitian pustaka. Apabila dilihat dari tempat di mana penelitian dilakukan, maka penelitian ini tergolong ke dalam kategori penelitian kepustakaan (libary research), yaitu penelitian yang obyek adalah buku-buku perpustakaan dan literatur-literatur lainnya (Hadi, 1983:3). Dalam analisis data kualitatif, metode yang digunakan dalam membahas sekaligus sebagai kerangka berpikir dalam kajian ini adalah metode deskriptif analitik yaitu: suatu usaha untuk mengumpulkan dan menyusun data, kemudian diusahakan pula adanya analisa dan interpretasi atau penafsiran terhadap data-data tersebut. Dalam analisis data kualitatif menggunakan cara: pola pikir deduktif yaitu pola pikir dari konsep abtrak yang lebih umum untuk mencari hal yang lebih spesifik atau konkret dan pola pikir induktif yaitu pola pikir yang berasal dari empiris dan mencari abstraksi-abstraksi. Lebih jelas lagi Hadi menjelaskan "penalaran induktif yaitu metode berpikir berangkat dari fakta-fakta yang khusus, peristiwa-peristiwa yang khusus itu ditarik generasi-genaralisasi yang sifatnya umum (Hadi, 1997:64).

\section{Pembahasan}

Konsep kecerdasan intelektual lahir akibat adanya berbagai tes mental yang dilakukan oleh para psikolog untuk menilai ke dalam berbagai tingkat kecerdasan yang kemudian lebih dikenal dengan Intellectual 
Quotient (IQ). Adapun faktor yang dapat mempengaruhi intelegensi, sehingga terdapat perbedaan intelegensi seseorang dengan yang lain ialah: pembawaan ditentukan oleh sifat-sifat dan ciri yang dibawa sejak lahir, kematangan, tiap organ (fisik maupun psikis) dapat dikatakan telah matang, jika ia telah mencapai kesanggupan menjalankan fungsinya masing-masing, pembentukan yaitu segala keadaan diluar diri seseorang yang mempengaruhi perkembangan intelegensi. Terdapat dua macam pembentukan, yaitu pembentukan sengaja (pengaruh alam sekitarnya), minat yang mengarahkan perbuatan kepada satu tujuan dan merupakan dorongan, kebebasan berarti manusia dapat memilih metode-metode tertentu dalam memecahkan masalah.

Pandangan lama menunjukkan bahwa kualitas intelegensi dipandang sebagai faktor yang mempengaruhi keberhasilan individu dalam belajar atau meraih kesuksesan dalam hidupnya. Namun dalam perkembangan selanjutnya muncul pandangan lain yang menyatakan bahwa faktor yang paling dominan dalam mempengaruhi kesuksesan individu semata-semata ditentukan oleh tingginya kecerdasan intelektualnya, tetapi oleh faktor pemantapan emosional.

Dalam diri seseorang pasti terdapat sifat yang berbeda. Begitu pula kemampuan pengendalian emosi. Ada orang bisa di bilang dewasa meskipun ia belum tua usianya, bahkan yang sudah tuapun sering kali masih ke kanak-kanakan. Hal ini masih sering terjadi, hanya karena kita perlu untuk mengenali emosi kita. Kesadaran diri mengenal perasaan itu, merupakan dasar kesadaran emosional. Kemampuan untuk memantau 
perasaan dari waktu ke waktu yang merupakan hal penting bagi wawasan psikologi dan pemahaman diri.

Bakat, kemampuan, sifat yang ada dalam diri harus selalu kita kelola agar menjadi suatu proses pematangan di dalamnya. Begitu pula emosi, maupun perasaan yang ada pada diri kita harus kita kelola agar kita bisa menjadi orang dapat membawa diri. Jika kita tidak mampu mengelola emosi, maka kita akan "terjerumus" ke dalamnya. Motivasi sangat diperlukan bagi diri manusia. Hal ini sebagai pemicu agar lebih bersemangat dalam menjalani hidup. Kita sedang mengalami penurunan semangat, penurunan gairah dan tidak mau terus bereaksi maka diperlukan supleman-supleman yang bisa membangkitkan semangat kita lagi.

Dalam pergaulannya yang terpenting adanya persamaan dalam memahami orang lain, khususnya dalam hal emosi sahabat kita. Hal ini sering disebut Goelman sebagai sikap empati. Orang yang memiliki empati tidak akan mampu memenangkan sinyal sosial yang tersembunyi yang mengisyaratkan apa-apa yang dibutuhkan atau yang dikehendaki orang lain. IQ dan EQ sebenarnya sudah ada dalam diri manusia, keduanya mempunyai kelebihan masing-masing. Kecerdasan Intelektual (kognitif) mengacu kepada kemampuan kita dalam berkonsentrasi, merencanakan dan mengelola bahan menggunakan kata-kata, memahami serta memaknai kata- kata tersebut. IQ cenderung mencapai puncaknya pada usia remaja usia 17 tahun, berjalan hingga usia dewasa dan mulai menurun ketika memasuki usia senja. 
Dalam artian tertentu, manusia mempunyai dua otak dan pikiran serta dua kecerdasan yang berlainan: kecerdasan rasional dan kecerdasan emosional. Keduanya mempunyai peran menentukan keberhasilan dalam kehidupan. Intelektualitas tidak dapat bekerja dengan baik tanpa kecerdasan emosional, demikian juga emosional tidak dapat berperan secara signifikan tanpa kecerdasan intelektual

Namun dalam kenyataan banyak orang tua yang kurang memahami adanya keterlibatan emosi dalam kegiatan syaraf otak yang dibutuhkan untuk merekatkan pelajaran dalam ingatan. Hal ini kurang bijaksana, sebab anak yang memiliki kecerdasan emosional yang tinggi pada umumnya akan lebih dapat mengatasi masalah, lebih tenang, lebih tabah, lebih konsentrasi dan lebih berani melakukan hal-hal yang baru. Sedangkan anak yang tidak memiliki konsentrasi dan lebih berani melakukan hal-hal yang baru. Sedangkan anak yang tidak memiliki kecerdasan emosional akan menyebabkan emosinya tidak stabil dan cenderung meninggi. Ini menjadi preseden kurang baik bagi perkembangan emosi anak di masa yang akan datang.

Belum sempat mencerna lebih dalam mengenai kecerdasan emosional, muncul konsep kecerdasan yang lebih mendalam yaitu kecerdasan spiritual. Konsep kecerdasan spiritual berhubungan erat dengan pengembangan kejiwaan yang berdimensi ketuhanan. Kecerdasan spiritual antara manusia dengan Tuhan (Ginanjar, 2000:89). Orientasi dari konsep kecerdasan ini bukan materi semata, lebih beriorentasi pada spiritualisme Tauhid (Ginanjar, 2001:14) contoh kecerdasan spiritual adalah ketika mengalami masalah, maka akan terjadi rangsangan pada 
dimensi emosi seperti kemarahan, kesedihan, kekesalan, atau ketakutan akan tetapi karena aspek mental telah dilindungi oleh prinsip tauhid, maka emosi akan terkendali dan suara hati pada dimensi spiritual bekerja dengan normal (Ginanjar, 2004:221)

Memahami kecerdasan spiritual sebagai hubungan manusia dengan Allah SWT membuat seseorang dengan mudah menemukan bahwa setiap aktivitas yang dilakukan adalah dalam rangka pengabdian kepada Allah SWT mengembalikan apapun hasilnya kepada Allah SWT (Inayati, 2002:33). Kecerdasan spiritual berarti menerima keputusan terakhir dari Allah SWT, sebab hal tersebut hal tersebut akan mendatangkan ketenangan dalam hidup. Dengan lima komponen tersebut akan terbentuk manusia yang bermental pimpinan senantiasa pemimpin senantiasa bekerja keras, tidak mudah putus asa dalam menghadapi cobaan dan tantangan namun tetap tunduk dan patuh terhadap patuh kepada Allah SWT.

Melalui penggabungan dua faktor yaitu kecerdasan emosi dan kecerdasan spiritual diharapkan akan lahir generasi yang sukses secara (duniawi) serta batiniah, ESQ (Emotional Spiritual Quotient) merupakan garis horizontal dan vertikal atau hubungan antara manusia dengan sesamanya dan hubungan antara manusia dan penciptaannya. Istilah kecerdasan spiritual atau spiritual quotient (SQ) pertama kali digagas oleh Danah Zohar dan Ian Marshal, pasangan suami istri yang berasal Havard dan Oxford University. Mereka mendifinisikan kecerdasan spiritual sebagai kecerdasan untuk menghadapi dan memecahkan 
persoalan makna dan nilai. Kecerdasan spiritual membantu manusia untuk memberi makna atas aktifitas yang dilakukan dalam kehidupan.

Dalam perkembangan selanjutnya, Ary gynanjar Agustian menggagas konsep baru yang menggabungkan kecerdasan emosional dan kecerdasan spiritual atau lebih dikenal dengan ESQ memegang peranan penting dalam membangun hubungan antar manusia serta meningkatkan kinerja. Sedangakan SQ mengajarkan nilai-nilai kebenaran yang berhubungan dengan sang pencipta meskipun keduanya berbeda, namun SQ dan EQ memiliki kekuatan yang sama-sama penting untuk bersinergi antara satu dengan yang lain, sehingga pada akhirnya nanti akan membentuk manusia yang seimbang antara hubungan dengan Allah SWT dengan sesama manusia.

Di dalam konsep Islam yang berhubungan dengan kecakapan emosi dan spiritual antara lain dapat dilihat dari sikap konsistensi (istiqomah), kerendahan hati (tawadhu'), berusaha dan berserah diri (tawakal), ketulusan (ikhlas), totalitas (kaffah), keseimbangan (tawazun), integritas dan penyempurnaan (ihsan), semua itu dinamakan ahlakul karimah. (Ginanjar, 2004:99). Untuk menjabarkan kecerdasan emosional dan spiritual yang sesuai dengan ajaran Islam, Ary memperkenalkan konsep ESQ yang langkah-langkahnya secara garis besar sebagai berikut: zero mind process atau menjernihkan hati yaitu membebaskan hati dan pikiran dari belenggu, misalnya seseorang harus bebas dari prasangka negatif, berprinsip hidup hanya kepada Allah SWT, membebaskan diri dari pengalaman-pengalaman yang membelenggu pikiran, mempertimbangkan semua aspek sebelum menentukan kepentingan dan 
prioritas dan melihat permasalahan dari semua sudut pandang yang bijaksana, yang bersumber dari suara hati (asmaul husna). Mental building atau membangun mental dengan landasan enam prinsip, yaitu: prinsip bintang, prinsip malaikat, prinsip kepemimpinan, prinsip pembelajaran, prinsip masa depan, dan prinsip keteraturan. Personal strength atau ketangguhan pribadi, yaitu langkah pengasahan hati berdasarkan rukun islam yang dimulai dari penetapan misi, pembangunan karakter dan pengendalian diri. Social strength atau ketangguhan sosial merupakan wujud dari tanggung jawab sosial seorang individu yang telah memiliki ketangguhan pribadi. Pelatihan yang diberikan, dinamakan langkah sinergi dan langkah aplikasi total.

Di dalam Islam secara langsung memang tidak ada istilah ESQ, yang kemudian diterjemahkan dalam bahasa Indonesia sebagai kecerdasan emosional dan spiritual, namun demikian ajaran agama Islam banyak sekali dipahami, direnungkan, diamalkan, bahwa ajaran Islam mampu mendatangkan banyak kemampuan pada manusia, termasuk potensi ESQ. Menurut Ary Ginanjar, ESQ (Emotional Spiritual Quotient) di bangun atas dasar enam rukun iman, rukun Islam, dan konsep ihsan.

Di dalam prinsip bintang, "anggukan universal" seperti dikemukakan Ary, merupakan "pengakuan jiwa" terhadap suatu kebenaran. Dan pada dasarnya anggukan universal merupakan suara hati manusia. Ary mengungkapakan bahwa 99 sifat Allah SWT terdapat dalam al-Qur'an yaitu asmaul husna merupakan sumber dari segala suara hati manusia (god spot). Sifat-sifat tersebut sering muncul sebagai suatu dorongan yang dirasakan di berbagai situasi berbeda (Ginanjar, 2001:69) 
Untuk memenuhi suara hati perlu disadari secara sungguhsungguh, bahwa semua sifat-sifat itu dirancang melalui satu kesatuan tauhid yang tidak dapat berdiri sendiri dan harus dilaksanakan secara seimbang. Misalnya seseorang yang mempunyai dorongan ingin berkuasa tidak bisa berdiri sendiri, harus memiliki sikap pengasih, penyanyang, serta adil. Contoh di atas merupakan cerminan dari Allah SWT yang Maha bijaksana (Ginanjar, 2001:72)

Prinsip bintang yang dibangun dan dilandasi iman kepada Allah SWT, akan menghasilkan individu yang memiliki kepercayaan diri yang tinggi, rasa aman, integritas yang kuat, bersikap bijaksana dan memiliki tingkat motivasi yang tinggi (Ginanjar, 2001:83) jika semua yang dihadapi manusia senantiasa dikembalikan kepada Allah SWT, maka sikap-sikap diatas bukan tidak mungkin akan terbentuk pada diri manusia itu sendiri. Angel principle, malaikat adalah mahluk ciptaan Allah yang berasal dari nur (cahaya), sangat dipercaya oleh Allah SWT untuk menjalankan segala perintah-Nya. Mereka melaksanakan tugas yang telah diamanatkan dengan sepenuh hati, penuh tanggung jawab, disiplin tinggi dan tidak kenal lelah, sehingga hasilnya sangat memuaskan dan sangat sempurna, tanpa cacat sedikut pun (Ginanjar, 2003:8). Penggambaran di atas sesuai firman Allah:

Maha suci ia tidak (mereka) hanyalah hamba-hamba yang dimuliakan. Tidaklah mereka malaikat mendahului-NYA berbicara, mereka (hanya) bertindak atas perintah-Nya (Qs. al-Anbinya ayat 26-27)

Keteladanan bisa diambil dari sifat malaikat secara umum adalah kepercayaan yang dimilikinya, loyalitas, dan integritas yang sangat mengagumkan (Ginanjar, 2003:85). Selain mengimaninya, dengan 
meneladani sifat malaikat, akan terbentuk manusia yang memiliki loyalitas yang tinggi (kesetian pada prinsip yang dianut ), komitmen yang kuat, memiliki kebiasaan untuk mengawali dan memberi, suka menolong dan memilki (Ginanjar, 2003:94). Leader principle, hampir setiap individu adalah pemimpin di lingkungannya, masing-masing, meskipun hanya satu orang yang menjadi pengikutnya, dia masih dikatakan pemimpin. Bahkan manusia seorang diri pun harus memimpin dirinya sendiri untuk mengarahkan hidupnya. Terlepas dari kedudukan resmi sebagai pemimpin setiap perbuatan dan tingkah laku seseorang dapat menimbulkan pengaruh di sekitarnya. Atau sebaliknya ia akan terpengaruh. Learning principle, membaca adalah awal dari suatu ilmu pengetahuan, teknologi, peradaban dan keberhasilan manusia. Wahyu Allah SWT diturunkan pertama kali kepada Nabi Muhammad SAW adalah "iqrā" (bacalah), hal ini menunjukan betapa pentingnya membaca, baik membaca buku, membaca lingkungan, situasi maupun membaca suatu fenomena yang ada disekeliling kita, dan yang terpenting selalu membaca al-Qur'an sebagai penyeimbang agar tidak terjerumus pada pemikiran yang keliru.

Al-Qur'an merupakan pedoman bagi manusia, sebab di dalamnya terdapat ajaran tentang kecerdasan emosional dan spiritual. Kecerdasan itu muncul dari iman, Islam dan ihsan. Oleh sebab itu manusia harus berpegang teguh pada al-Qur'an sebagai pedoman. Vision principle, pada prinsip masa depan yaitu pembangunan visi, tahap pembentukannya akan sangat tergantung pada kualitas kecerdasan hati yang terbentuk pada sebelumnya. Visi yang dibangun akan sulit berjalan dengan baik apabila 
prinsip-prinsip yang dianut sejak awal kurang tepat, sehingga pada tahap vision principle ini akan membangun suatu visi yang goyah atau bahkan visi yang keliru. Untuk membangun visi yang benar, seseorang harus selalu beriorentasi pada tujuan akhir dalam setiap langkah yang dibuat, dan melakukan upaya secara optimal dan sungguh-sungguh dalam setiap langkahnya serta memiliki kendali diri dan sosial karena telah menyadari akan adanya "hari kemudian", demikian pula harus memiliki kepastian akan masa depan dan memiliki ketenangan batiniah yang tercipta oleh kenyakinan akan adanya hari pembalasan. Melalui upaya di atas, diharapkan kemenangan dapat diraih baik dunia maupun di "hari kemudian." Well organized principle, sebelum melaksanakan suatu program yang telah dirancang, seseorang harus memiliki perencanaan yang matang, agar tujuan yang dicapai dapat tercapai, meskipun pada akhirnya nanti ternyata akan menghadapi kegagalan, namun yang terpenting telah melalui suatu proses yang mana di dalam setiap proses tersebut memiliki takdir atau ketentuan-ketentuan sendiri-sendiri. Banyak orang beraggapan bahwa keberhasilan atau kegagalan seseorang sematamata adalah Takdir Tuhan. Secara prinsip, hal tersebut memang benar. Namun sebelum mencapai takdir keberhasilan atau takdir kegagalan, perlu adanya suatu proses yang dihadapi satu per satu.

Hal-hal yang dapat dilakukan pada prinsip keteraturan menurut Ginanjar (2003:171) antara lain: dapat membuat sistem yang teratur, menentukan rencana atau tujuan yang jelas, membuat sistem motivasi agar bergerak sesuai harapan, memperhatikan sistem pengawasan dan kontrolnya sesuai dengan rencana dan melaksanakan program yang 
dituju dengan kedisiplinan dan kesadaran diri, bukan karena orang lain. Prinsip-prnsip yang telah dikemukakan di atas tidak dapat di pisahpisahkan dan diubah urutannya, sebab antara satu sama lainnya memiliki keterkaitanya yang erat, yang nantinya akan membentuk seseorang yang memiliki ketangguhan pribadi.

Perintah Allah SWT untuk mengucapkan syahadat merupakan mission statement dalam kehidupan ini sebagai misi yang sesungguhnya. Kenyakinan syahadat bila ditanamkan kuat-kuat di dalam hati, maka akan terbentuk kekuatan yang mendorong jiwa manusia untuk bergerak mencapai misinya, dan selanjutnya akan memunculkan suatu keberanian, kenyakinan, optimisme, dan ketenangan batin sebagai perwujuadan untuk mencapai visi dan cita-citanya. Pengakuan pada Allah SWT berupa pengucapan ikrar kalimat syahadat, berarti berkomitmen total untuk patuh dan taat (beriman) menjauhi segala larangannya dan mematuhi segala perintah-Nya.

Sedangkan pengakuan kepada Rasulullah berfungsi membangun kesadaran sendiri, sehingga sebuah doktrin yang menghasilkan sebuah karakter yang mengacu kepada Rosulullah (Ginanjar, 2003:181-191). Character building; kewajiban shalat diperintahkan oleh Allah SWT secara langsung kepada manusia melalui Rosulullah ketika beliau melakukan isrā' mi'rāj. Shalat merupakan suatu cara dalam pembentukan karakter manusia. Sebab shalat berbagai fungsi, antara lain: salat sebagai suatu metode relaksasi untuk menjaga kesadaran diri dan menstabilkan kecerdasan emosional dan spiritual seseorang agar tetap 
memiliki cara berfikir yang fitrah, Shalat adalah suatu metode untuk meningkatkan kecerdasan emosional spiritual secara terus menerus.

Robert K. Cooper dan Ayman Sawaf memberikan suatu metode untuk meningkatkan kecerdasan emosi, yaitu: meluangkan waktu dua atau tiga menit untuk duduk dengan tenang, pasang telinga hati, keluar dari fikiran dan masuk dalam hati, tulis apa yang sedang dirasakan. Cara ini akan mendatangkan kejujuran hati. Pada prinsip bintang yang sudah dikemukakan di depan menjelaskan bahwa kecerdasan emosional dan spiritual bersumber pada suara-suara hati yang berasal dari sifat-sifat illahiyah, seperti dorongan ingin belajar, dorongan bijaksana, dan dorongan-dorongan yang lain.

Sedangkan sholat berisi tentang pokok pikiran dan bacaan suara hati, seperti ucapan Maha Besar Allah, Maha Pengasih dan Penyanyang yang akan menjadi reinforment atau penguatan kembali akan pentingnya suara hati mulia tersebut, sehingga sumber-sumber ESQ itu akan hidup untuk mencerdaskan emosi dan spiritual sekaligus kepekaan hati. Shalat merupakan teknik pembentukan pengalaman yang membangun paradigma positif (new paradigm shift). Melakukan sholat secara rutin dapat menciptakan suatu pengalaman batiniah dan pengalaman fisik yang akan mempengaruhi pola pikir dan karakter seseorang ke arah positif, misalnya: sujud di lantai menunjukkan suatu pengakuan yang tidak hanya dilakukan secara pikiran tetapi juga dilaksanakan secara fisik, bahwa kita hanya menyembah Allah SWT dan tidak ada yang patut di sembah selain Allah SWT. 
Shalat adalah salah satu cara untuk terus mengasah dan mempertajam ESQ yang diperoleh dari rukun Iman adalah Pengendalian Diri (self controling) yang bertujuan untuk meraih kemerdekaan sejati dengan cara menahan diri dari belenggu nafsu duniawi sehingga kecerdasan emosi (god spot) seseorang tidak tertutup oleh nafsu yang akan membutakannya. Salah satu manfaat puasa adalah sebagai bentuk pelatihan menjaga suasana hati agar tetap berpikir jernih dan bertindak positif dan produktif sehingga ledakan emosi dapat terkendali.

Mission statement, character building, self controling merupakan metode yang bertujuan membangun ketangguhan pribadi sedangkan dalam strategic collaboration yang berbentuk zakat merupakan metode membangun ketangguhan sosial. Zakat adalah langkah nyata membangun suatu landasan yang kokoh guna membangun sebuah sinergi yang kuat yaitu: berlandaskan sikap empati, kepercayaan, sikap koperalatif dan keterbukaan serta kredibilitas (Ginanjar, 2004:260).

Haji merupakan perwujudan akhir dari Rukun Islam dan lambang dari puncak "ketangguhan sosial" rangkaian ibadah yang dilakukan dengan gerakan yang kongkrit di dalam haji adalah sublimasi dari keseluiruhan kecerdasan emosional dan spiritual (ESQ) berdasarkan rukun iman dan rukun Islam. Di saat ibadah inilah prinsip zero mind process terdapat pada amalan-amalan ibadah haji, sebagaimana ihram, thawaf sebagai pengesahan komitmen dan integritas, sai' menunjukkan nilai perjuangan, wukuf merupakan langkah evaluasi dari langkah yang telah dibuat. Visiualisasi masa depan melaui prinsip berfikir dan cara melangkah yang fitrah, sedangkan lontar jumrah merupakan pelatihan 
sinergi dalam skala tertinggi dan sebagai persiapan fisik dan mental dalam menghadapi berbagai tantangan masa depan (Ginanjar, 2004:282).

Demikianlah tata urutan dalam rukun iman sehingga rukun Islam yang ternyata disusun berdasarkan satu tingkatan anak tangga yang teratur dan sistematis, serta memiliki keterkaitan yang erat, di mulai dari pembangunan mental yang berdasarkan prinsip bintang hingga prinsip keteraturan, kemudian pembentukan ketangguhan pribadi dialnjutkan dengan pembentukan ketangguhan sosial melalui zakat dan haji (strategic collaboration dan total action). Kunci dasar dari rukun iman dan rukun Islam adalah asmaul husna yang kemudian merupakan sumber dari suara hati manusia.

Adapun kunci ihsan adalah beribadah kepada Allah SWT seakanseakan engkau melihat-Nya dan seandainya engkau tidak dapat melihatNya, engkau yakin bahwa Dia melihatmu" (Ginanjar, 2004:137) Dengan demikian, ketika manusia mampu beribadah sebagaimana disebutkan, maka ibadah menjadi khusu' dan penuh keikhlasan. Namun bentuk ibadah semacam itu tidak dapat dilaksanakan secara instan, butuh proses dan usaha yang terus menerus tanpa henti.

Quantum leap atau loncatan besar di bidang teknologi terjadi dengan lahirnya era digital, yaitu semenjak ditemukannya bilangan biner 0 dan 1 Digital adalah susunan angka yang terdiri dari 0 dan 1 . Dengan adanya sistem tersebut, berbagai bidang teknologi mengalami perkembangan yang sangat pesat (Ginanjar, 2004:231). Sebagaimana bilangan angka 0 dan 1 dikenal pula dalam digitalisasi spiritual yang mampu mengantarkan nilai spiritual murni yang bersumber dari Allah 
SWT, yang diturunkan ke muka bumi melalui manusia, kemudian kembali lagi kepada Sang Pencipta.

Tahapan tranformasi kekuatan spiritual dalam diri manusia sebagaimana diungkapkan Ginanjar (2004:232) adalah pada tahap awal penciptaan manusia, Tuhan menciptakan nilai (value) yang bersumber dari Allah Yang Maha Esa, sumber nilai yang dilambangkan dengan bilangan biner (1), pada tahap kedua, agar nilai ilahiah yang diberikan kepada manusia tetap utuh, maka manusia harus menzerokah dirinya dihadapan Allah (0). Pada tahap ketiga manusia harus membangun prinsip Tauhid kepada Tuhan Yang Maha Esa, Tujuannya agar tarnsformasi spiritual tetap berjalan (1). Manusia harus mampu menahan stabilitas emosinya (EQ) pada posisi (0), agar spiritualnya bisa ditransformasikan kepada God Spot. Belenggu yang menutup God Spot pada dimensi spiritual (SQ) harus dalam posisi (0). Pada Tingkatan selanjutnya, karena posisi belenggu God Spot dalam posisi (0), maka akan ditransformasikan dan melahirkan nilai-nilai fitrah untuk disebarkan ke muka bumi sebagai rahmatan lil alamin (1). Pada bagian akhir, manusia mati (0). Energi dan nilai-nilai tersebut ditransformasikan kembali kepada pemiliknya (1), Allah Yang Maha Mengembalikan.

Kalimat Tauhid, Lā ilāha Illallāh sesungguhnya adalah kalimat yang mengajarkan transformasi energi spiritualitas tidak ada Tuhan (0), selain Allah (1). Di hadapkan Allah manusia menjadi zero dan dalam alam pikirannya hanyalah ada Allah yang satu, sebagai pusat prinsip manusia. Dengan demikian Tauhid, spritual power dan spiritual value mampu dihadirkan oleh seorang manusia ke dalam dirinya sebagai 
khalifah di muka bumi, sehingga ia akan mampu menjadi manusia yang mempunyai mental digital.

Perkembangan teknologi setelah era digital, perlu di imbangi dengan lahirnya manusia yang bermental digital, sehingga tidak akan terjadi penyimpangan dalam penggunaan bidang teknologi yang mengalami perkembangan terus-menerus. Dalam mengemukakan konsep ihsan Ary Ginanjar, memperkenalkan rumus ihsan sebagai berikut:

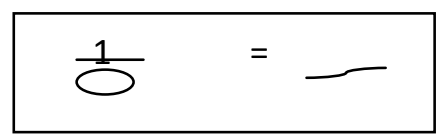

Angka 1 apabila dibagi (nol) hasilnya hampir tak terhingga. Artinya apabila manusia menuhankan Allah Yang Maha Satu (Esa) dan kemudian ia meletakkan dirinya sebagai hamba, dengan menzerokan diri di hadapan-Nya, maka ia akan menuju taqarub kepada kekuatan sang Maha Tak Terhingga. Artinya Allah-lah yang akan menolong kita dengan kekuatan-Nya yang luar biasa.

\section{Peranan Orang Tua dalam Mengembangkan Kecerdasan Emosional dan Spiritual Anak Perspektif Islam}

Kunci pendidikan dalam rumah tangga sebenarnya terletak pada pendidikan rohani atau pendidikan agama. Sebab pendidikan agama mempunyai dua fungsi yaitu, sebagai penanaman nilai dalam arti pandangan hidup, yang kelak mewarnai perkembangan jasmani dan akalnya dan sebagai penanaman sikap yang kelak menjadi basis dalam menghargai guru dan pengetahuan di sekolah (Tafsir, 2001:157). Sehingga manakala sebuah keluarga menanamkan nilai-nilai keagamaan 
kepada anak-anak secara baik, maka anak-anak tersebut akan tumbuh berkembang dengan baik pula.

Orang tua memegang peranan penting dan amat berpengaruh atas pendidikan atas anak-anaknya. Sejak anak lahir yang mula-mula dikenal dan tercapainya adalah ibunya, karena itu seorang anak lebih sering meniru perangi ibunya. Sedangkan ayahnya dianggap sebagai penolong utama, lebih-lebih jika anak besar, ia juga dianggap sebagai orang terpandai diantara orang-orang yang dikenalnya (Darajat, 1996:35). Orang tua yang shalih merupakan suri tauladan yang baik bagi perkembangan jiwa anak yang sedang tumbuh karena pengaruh mereka sangat besar sekali dalam pendidikan anak. Apabila orang tua sudah berakhlak baik, taat kepada Allah SWT, menjalankan syariat Islam, berjuang sepenuhnya di jalan Allah SWT serta memiliki jiwa sosial, maka dalam diri anak pun akan mulai terbentuk dan tumbuh sebagaimana sikap dan perilaku orang tua dalam perilaku mereka sehari-hari (Hafidz, 1997:65). Adapun menurut Suharsono (2002:101), orang tua mempunyai tanggung jawab dan tugas untuk memberikan pendidikan-pendidikan guna mengembangkan potensi-potensi dasar manusiawi yang dimilikinya. Sebab potensi yang dimiliki anak tidak dapat berkembang secara optimal manakala orang tua tidak memberikan perhatian secara optimal, sehingga mengembangkan potensi yang dimiliki oleh anak, khususnya kecerdasan intelektual, kecerdasan emosional dan kecerdasan sosial pada mulanya ada di tangan orang tua.

Begitu pentingnya peranan orang tua dalam mengembangkan kecerdasan emosional dan sipiritual pada periode awal tahun kehidupan 
anak-anak, karena dapat menjadi peganggan anak pada perkembangan selanjutnya. Oleh karena itu, sudah seharusnya orang tua memperlakukan anak dengan baik dan memberikan kesempatan pada anak-anaknya untuk berkembang, baik secara intelektual, emosional maupun spiritual. Dengan demikian orang tua telah menumbuh kembangkan ESQ anak.

Untuk dapat mengembangkan kecerdasan emosional dan spiritual anak sesuai dengan ajaran Islam orang tua perlu melakukan beberapa hal, diantara sebagai berikut: anak perlu diajak untuk mengenal penciptaannya melalui ciptaan-Nya, misalnya dengan mengajak mereka melihat keindahan pemandangan, sehingga dapat mengundang kekaguman akan kebesaran Allah SWT. Sejak usia dini, orang tua harus mengenal anak pada keagungan Allah SWT, agar mereka menyadari bahwa segala sesuai di alam ini yang mengatur, sesuai firman Allah:

"Kepunyaan-Nya siapa yang ada dilangit dan dibumi, semuanya tunduk dan patuh) kepada-Nya. (Qs. Al- Rum:26)

Emosi seorang anak perlu dilatih dan dikelola orang tua, agar ia bisa menjadi orang yang dapat membawa diri dan tidak terjerumus ke dalam emosi itu sendiri. Pentingnya pengendalian diri tersebut, Allah SWT telah berfirman:

"Sekiannya kebenaran mengikuti hawa nafsu mereka, niscaya binasalah langit dan bumi dan siapa-siapa yang ada di dalamanya" (Qs. alMu'minun: 17)

Salah satu cara yang dapat dilakukan orang tua untuk melatih emosi anaknya adalah dengan memberikan suatu hadiah apabila ia berhasil menahan diri tidak menonton TV sehari misalnya. Cara-cara lain 
sejenis dapat dilatihkan oleh orang tua selama betujuan agar anak pandai mengelola emosi dan kelak menjadi orang yang tidak terbiasa memperturutkan hawa nafsunya. Melatih anak agar mampu memotivasi diri sendiri, motivasi sangat diprlukan sebagai pemicu semangat dalam menjalani kehidupan. Sebab hal tersebut mampu menjadi energi ketika individu menghadapi tantangan dan persoalan hidup kelak ketika ia telah dewasa. Allah SWT berfirman :

"Dan janganlah kamu berputus asa dari rahmat Allah. Sesungguhnya tidak ada yang berputus asa dari rahmat Allah kecuali orang yang kafir".

Selain hal diatas, Inayati (2002:28) menyatakan langkah yang perlu dilakukan oleh orang tua untuk mengembangkan ESQ anak antara lain: 1) membersihkan jiwa anak, rasa Ingin tahu pada anak menunjukkan bahwa anak memiliki kecerdasan emosional dan spiritual yang tinggi dan dorongan untuk belajar masih tinggi. Orang tua harus berusaha untuk tidak melakukan tindakan yang mematikan kreatifitas anaknya, sehingga pikirannya akan terbelenggu. Sesuai dengan konsep zero mind process misalnya, agar anak senantiasa bebas mengekpresikan emosinya (namun dalam batasan yang wajar) orang tua harus memberikan contoh sikap ketika sedang marah; 2) merumuskan misi hidup, anak-anak butuh bantuan untuk merumuskan misi hidupnya melalui dialog atau diskusi dengan anak, karena biasanya mereka tidak mengetahui apa yang ingin dicapai dalam jangka waktu yang pendek, menengah terlebih jangka panjang; 3) mendiskusikan berbagai persoalan dengan prespektif ruhaniah, anak-anak harus diberi kesempatan dalam mengungkapkan 
perasaan-perasaan dengan bebas. Seperti rasa marah, sedih, takut, dan kecewa.

Namun mereka tetap butuh diajarkan bahwa semua yang terjadi berada dalam rencana Allah SWT. Selain berperan sebagai pendengar dan teman yang baik, orang tua juga mengajak untuk memahami bahwa Allah SWT mempunyai maksud dalam setiap peristiwa; 4) melibatkan anak dalam ritual keagamaan, mengajarkan anak untuk melakukan berbagai ibadah perlu dilakukan. Namun selain itu, anak juga dia jarkan makna ibadah yang dilakukan misalnya, salat bukan sekedar dari kewajiban, namun sebagai penghormatan kepada Allah SWT.

Langkah-langkah diatas dapat membantu mengembangkan Emosional Spiritual (ESQ) pada anak. Sebab potensi anak tidak tumbuh dengan sendirinya tanpa dirangsang. Dan orang tua perlu menyajikan lingkungan yang kondusif bagi perkembangan kecerdasan dan kehidupan anak secara umum. Untuk dapat memancing potensi pada anak, orang itu harus memahami fase-fase perkembangan mereka.

Selain hal di atas, berdasarkan ajaran agama Islam, untuk mengembangkan kecerdasan emosional spiritual anak, orang tua harus memberikan nafkah yang halal dan senantiasa mendoakan kebaikan bagi anak. Karena hal tersebut secara langsung menjadi bagian penting bagi pembentukan anak yang cerdas, baik secara intelektual emosional maupun spiritual. 


\section{Simpulan}

Berdasarkan paparan yang telah disampaikan sebelumnya, maka penulis dapat menarik beberapa kesimpulan dari penelitian ini, di antaranya: menurut Ary Ginanjar Agustian, kecerdasan emosional dan spiritual (ESQ) merupakan penggabungan dari kecerdasan emosional yang membentuk hubungan dengan sesama manusia, dan kecerdasan spiritual yang membentuk hubungan dengan Allah SWT, sehingga pada akhirnya terbentuk hubungan dengan Allah SWT dan sesamanya. Asmaul Husna merupakan kunci dari pengembangan emositional dan spiritual dalam membentuk akhlak yang mulia, sebab sumber dari suasana hati manusia adalah asmaul husna itu sendiri.

Perkembangan anak usia 2-6 tahun yang menonjol adalah mudahnya untuk marah, takut dan hal-hal yang berhubungan dengan sifat emosional, dimana pada akhirnya anak sulit ditangani. Karakter emosional yang lebih muncul disebabkan oleh faktor psikologis dari pada fisologis. Pada usia tersebut anak mulai ada rasa ingin tahu yang tinggi. Dan secara umum pematangan dan faktor belajar sangat mempengaruhi perkembangan emosi anak.

Perkembangan spiritual anak usia 2-6 tahun antara lain: pada usia 2 tahun anak belum mempunyai perasaan yang tampak, tetapi akan tampak pada usia 3 tahun ketertarikan dan pertanyaan anak mengenai Tuhan. Pada usia ini anak mulai mengenal dan menyukai sembahyang, namun mengerjakannya dengan caranya sendiri. Bila anak mendapatkan pendidikan agama yang baik, maka pada usia 6 tahun anak telah 
memahami bahwa segala sesuatu yang ada di alam ini adalah ciptaan Allah SWT.

Cara-cara yang dianggap paling tepat dalam mengembangkan kecerdasan emosional dan spiritual anak sangat beragam. Akan tetapi, secara umum dapat dijelaskan sebagai berikut: orang tua harus membersihkan jiwa anak dari hal-hal non-fitrah sehingga potensinya akan berkembang dengan optimal, membantu anak untuk merumuskan misi hidupnya, memberikan gambaran orang-orang yang berkepribadian yang mulai melalui cerita atau dongeng sehingga anak terinspirasi untuk menirunya, menjalin komunikasi yang baik melalui diskusi di berbagai persoalan untuk mengembangkan ESQ anak diperlukan suatu lingkungan yang kondusif dan sesuai dengan pandangan islam, orang tua harus memberikan teladan yang baik, memberikan nafkah yang halal dan mendoakan kebaikan untuk anak.

\section{Daftar Pustaka}

Agustian, A. G. (2001). Menggali Potensi ESQ. Khazanah Sabili No. 14 Th IX.

Agustian, A. G. (2003). Kata Pengantar Belajar EQ dan SQ dari sunnah Nabi, Karya M. Usman Najati. Jakarta: Hikmah.

Agustian, A. G. (2004). ESQ Power Sebuah Inner Journey Melalui alIhsan. Jakarta: Arga.

Agustian, A. G. (2005). Rahasia Sukses Membangun Kecerdasan Emosi dan Spiritual Berdasarkan 6 Rukun Iman dan 5 Rukun Islam. Jakarta: Arga.

Al-Mundiri, A. Z. A. (2002). Ringkasan Shahih Muslim, terj. Syingithi Djamaluddin. Bandung: Mizan. 
Mudarrisa, Jurnal Kajian Pendidikan Islam, Vol. 8, No. 2, Desember 2016: 229-254

Darajat, Z. (1996). Ilmu Pendidikan Islam. Jakarta: Bumi Aksara.

Darajat, Z. (1970). Ilmu Jiwa Agama. Jakarta: Bulan Bintang.

Hadi, S. (1983). Metodologi Penelitian I. Yogyakarta: Gajah Mada.

Hafidz, M. N. A. (1997). Mendidik Anak bersama Rasulullah. Bandung: Mizan.

Inayati. (2002). Mengembangkan Kecerdasan Spiritual Anak. Majalah Ummi edisi 4.

Suharsono. (2002). Mencerdaskan Anak. Depok: Iniasi Press.

Tafsir, A. (2001). Ilmu Pendidikan dalam Perspektif Islam. Bandung: Rusda Karya. 